\title{
Love Old Sweet Song: How Joyce Narrativizes with Music? ${ }^{1}$
}

The literary output of really few writers' boasts such extensive criticism focused on musical context as that by James Joyce. Almost immediately after Ulysses and Finnegans Wake were published, they prompted a number of critical texts written about their musical contexts. These analyses covered the way music is thematized, enumerated references to particular musical compositions as well as pointed to the elements of the literary work's structure that are inspired by music. This is hardly surprising when to consider the fact that not only did Joyce himself not deny such interpretations, but also provided his critics with more detailed guidelines (cf. Gilbert 1963: 88; Budgen 1963: 130). This is particularly true of Ulysses. The novel's protagonists are characterised by highly developed musical awareness: they are well-versed in popular songs as well as opera and operetta arias, they hum tunes, organise concerts, play the piano, enjoy themselves, discuss the performance and the performers, try to determine whether the church bell chimes in tune or identify the metre of the printing press.

Deeply inspired by music, such an approach to literature was nothing extraordinary in Joyce's times. The problem of the musical involvement of literature and writing, and of how music is discussed, is associated with a certain aspect of aesthetic awareness, exhibited by both the authors and their works' recipients (cf. Wiegandt 2002: 63-64). James Joyce, but also Édouard Dujardin, Thomas Mann, Aldous Huxley, and numerous other writers who have been associated in literary criticism with attempts at transgressing the boundaries of "classical" prose, have talked of their musical inspiration, particularly with Wagnerian leitmotifs. It ought to be remembered that music, with its vagueness, so-called sensibility, and

1 This research project has been funded by the National Science Centre in Poland, according to the decision no. DEC-2013/11/N/HS2/03302. 
autoreferentiality, was the ideal to be strived for, particularly in the case of symbolism, which set a goal for every art form: to become like music (Schopenhauer). With his concepts of a total work of art and leitmotif, Wagner was particularly venerated in that respect.

In his Trieste home, Joyce had quite a little collection of books about Wagner, which included both critical works and sheet music with librettos (cf. Martin 2009: 276), even though apart from The Master-Singers of Nuremberg he did not care for the German composer's music. Being an opera lover and an amateur tenor singer, the Irish writer was coaxed by his teachers to make it his professional career. He would perform the quintet from The Master-Singers on stage, quite a challenging feat for an amateur; and was even once awarded the third prize in Feis Ceoil (cf. Martin 2009: 277), a Dublin music festival. Some of his acquaintances claimed Joyce's dedicated support of John Sullivan during his stay in Paris stemmed from his perception of the Irish tenor's career as an outlet for his own unfulfilled ambitions (cf. Hodgart, Bauerle 1997: 75-92; Beach 1959: 44). Having been raised in a family with vivid musical traditions, in cities rich in cultural traditions, allowed Joyce to mould his tastes and fancies, which were focused on operas and religious songs, particularly the Irish ones. Interestingly, Joyce was not fond of modern music and remained faithful to bel canto, Rossini, Meyerbeer, and Verdi (Martin 2009: 277; Potts 1979: 168).

In the works of the Irish author, music is a particular intertextual reference point. ${ }^{2}$ Although all Joyce's works prior to Ulysses (such us Chamber Music, Dubliners, A Portrait of the Artist as a Young Man) refer to music, nowhere before had these references been implemented in the way they functioned in Ulysses. Not only do they constitute an illustration for the novel, but also influence its style, spirit, structure, and themes. Zach Bowen enumerates 700 allusions to various musical pieces, at the same time claiming that the list is by no means complete (1995: 46). We must be aware of the fact that the referenced titles and lyrics (of operas, popular Irish folk and religious songs, as well as musicals) were commonly familiar to

${ }^{2}$ Musical sensibilities and taste for opera are manifested in Joyce's works, among others, in their rhythmical and tonal outline. The author is sensitive to rhythm; reading Ulysses and Finnegans Wake aloud can open them up to new interpretations. The critics point to another constructive level of musical inspiration: Ulysses is supposedly constructed like a sonata form, whereas alternating prose and poetry in "Cyclops" can be read as the literary equivalent of arias and recitatives, although Joyce himself explicitly speaks about the musical form only in reference to "Sirens". I elaborate on this aspect of Joyce's prose, that is his inspiration with musical forms, textures, and means of articulation, in another article of mine (cf. Barska 2012: 7-33). 
Joyce's contemporaries, particularly the Irish. ${ }^{3}$ In this way, Ulysses creates a network of intertextual references to musical compositions in the same way it does to the Bible, titles of literary works, and myths. Because of that the reception of the novel is not that easy for modern readers, particularly those reading translations, since the quoted lyrics of Irish songs do not automatically evoke the associations implied by Joyce. Without further ado, let us look at the example of "Circe", in whose episode the titles of musical pieces refer us to once well-known characters. "The Man Who Broke the Bank at Monte Carlo", "The Bowld Sojer Boy", "The Collen Bawn", "The Lily of Killarney" increase the number of characters in the episode, thereby intensifying its hallucinatory qualities. Joyce also eagerly employs music to underscore certain parts of the narrative and the significance of the protagonists' words, who refer to musical allusion in their thoughts and conversations (cf. Bowen 1995: 46).

I do not wish to make this paper one of the works that attempt to quote as many passages and other references present in Ulysses, as it would perforce make them a type of a glossary devoid of any developed interpretative concepts. Instead, I will rather focus on the way Joyce "employs" musical compositions present in the "Sirens" episode, which in my opinion are essential for our understanding of Ulysses. The episode is a tale of Leopold Bloom, an advertising agent, who correctly suspects his wife Molly, an opera singer, of having an affair with Blazes Boylan, her impresario. The meeting of two lovers' is set for 4 p.m. and Bloom, who is aware of it, spends his day pacing the streets of Dublin, attending to his various errands, and finally, upon seeing Boylan's carriage in front of the Ormond bar, choses it as a place to have his lunch. Bloom could easily prevent the tryst by coming home earlier, before Boylan's arrival, but instead decides to do nothing. Sitting in the restaurant, he can overhear everything that is happening in the adjacent barroom and so he listens to the conversations of his acquaintances, who talk, among other things, about his wife. He eats his lunch, writes a reply to a letter he received from Martha, whom he engaged in an epistolary flirtation, and ponders on his situation.

The arias and songs most frequently appearing in the barroom scene, either performed by regular customers on the bar's piano, referenced in conversations, or recollected by Bloom, introduce the theme of loneliness and the loss of a loved one; they evoke specific emotions. I particularly

${ }^{3}$ Modern readers must resort to works by the scholars who have dedicated entire volumes to the musical intertextuality of Joyce's works, e.g. Hodgart and Bauerle 1997; Bowen 1995; Hodgart and Worthington 1959. 
mean: "Goodbye, Sweetheart, Goodbye", "All Is Lost Now", and "When first ISaw That Form Endearing". The first song is sung when Boylan enters the Ormond bar. His acquaintances welcome him with the words: "See the conquering hero comes", referring directly to Handel's Judas Maccabaeus, ${ }^{4}$ although the metaphorical "confrontation" between him and Bloom has not happened yet. "Between the car and window, warily walking, went Bloom, unconquered hero". The fact that Bloom is thus described may also be associated with the fact he has already reconciled himself to his wife's infidelity. In "Sirens" the composition "ascribed" to him is a calm, sentimental ballad, "The Bloom Is on the Rye". It functions exactly in the same way as a Wagnerian leitmotif. Joyce introduces characteristic "leitmotifs" which announce the arrival of a particular character, e.g. "The bag of Goulding, Collis, Ward led Bloom by reybloom flowered tables" (266.910), ${ }^{5}$ which reminisces the aforementioned ballad and announces the change of the narrative's perspective to Bloom's stream of consciousness. The juxtaposition of what we might call "Bloom's theme" and the pompous and triumphant quote from Handel ascribed to Boylan gives us a certain idea about the characters and attitudes of each of the protagonists.

One of the bar's patrons performs an aria from the second act of Vinzenzo Bellini's The Sleepwalker, with the libretto by Felice Romani. The aria, "Tutto è Sciolto", is translated as "All Is Lost Now":

All is lost now,

By all hope and joy am I forsaken.

Nevermore can love awaken.

Past enchantment, no, nevermore. (qtd. in Bowen 1995: 41)

This poignant piece reflects the hopeless situation in which Bloom had found himself, and it is he who cites the context of the opera the aria comes from.

The first act of The Sleepwalker begins with preparations for a wedding between Amina and Elvino, unexpectedly interrupted by the appearance of Rudolfo, a young nobleman and the son of a local landlord. The compliments he pays to Amina make her fiancé jealous, but the couple reconciles, and Rudolfo remains at their home for the night as a guest. At night, he witnesses Amina sleepwalking, an affliction she suffers from. She walks into the guest's room and lies down on the sofa; to

${ }^{4}$ I quote both the allusions to the given musical works as well the references from Bowen 1995: 25-76.

${ }^{5}$ All references to Ulysses in this article come from James Joyce, Ulysses: The Corrected Text. The citations refer to an episode and line number. 
protect her honour, the count leaves the room. The scene is however witnessed by Lisa, who is in love with Elvino and wishes to break up his relationship with Amina. Lisa fetches Elvino and the wedding guests. Jumping to conclusions, Elvino entirely ignores his fiancée's protestations of innocence. In act two, Elvino breaks up their engagement. The count explains the nature of somnambulism and his lecture is interrupted by Amina sleepwalking into the room. The woman tells of her love for Elvino and her despair, and when she wakes up, her beloved offers the engagement ring back to her.

"All Is Lost Now", sung by Elvino, is full of despair and an expression of how he sees his situation as hopeless, having been seemingly betrayed by his fiancée. Although Bloom's own situation is not literally reflected in The Sleepwalker's libretto, the protagonist himself draws a parallel between the plot of the opera and his own situation:

Bloom bent leopold ear, turning a fringe of doyley down under the vase. Order. Yes, I remember. Lovely air. In sleep she went to him. Innocence in the moon. Still hold her back. Brave, don't know their danger. Call name. Touch water. Jingle jaunty. Too late. She longed to go. That's why. Woman. As easy stop the sea. Yes: all is lost. (272.41273.4)

The protagonist is focused on the libretto until he comes to think of Boylan ("Jingle jaunty" refers to the sound made by the impresario's carriage). From that moment on, the story of Amina is combined with Molly's betrayal. For Bloom-Elvino "all is lost". When he again focuses his attention on the piano, he hears another soulful aria, "M'appari" from Friedrich von Flotow's Martha, or The Market at Richmond, with the libretto by Friedrich Wilhelm Riese.

Lionel's aria begins with “M'appari, tutt' amor, il mios guardo l'incontro" ("All [perfect] love appeared to me, that encounter filled my eyes [completely won me]"). Joyce employs a more liberal translation by Charles Jeffreys:

When first I saw that form endearing;

Sorrow from me seem'd to depart:

Each graceful look, each word so cheering

Charm'd my eye and won my heart.

Full of hope, and all delighted,

None could feel more blest than I;

All on Earth I then could wish for

Was near her to live and die:

But alas! 'twas idle dreaming,

And the dream too soon hath flown;

Not one ray of hope is gleaming; 
I am lost, yes I am lost for she is gone.

When first I saw that form endearing

Sorrow from me seem'd to depart:

Each graceful look, each word so cheering

Charm'd my eye and won my heart.

Martha, Martha, I am sighing

I am weeping still; for thee;

Come thou lost one,

Come thou dear one,

Thou alone can'st comfort me:

Ah Martha return! Come to me! (qtd. in Bowen 1995: 45)

Lady Harriet Durham, maid of honour to Queen Anne, dresses up as a servant, adopts the name of "Martha", and together with her maid Nancy goes to the Richmond market to escape the boredom of courtly life. At the market "Martha" and Nancy encounter Lionel and Plunkett, two rich farmers who came to the market fair for the purpose of finding servants. "Martha" and Nancy unwittingly sign contracts. Their presence causes a lot of confusion, both in the working and love lives of all parties concerned. "Martha" reports her feelings for Lionel in "This the Last Rose of Summer" aria. When the women flee back to the court, the grieving Lionel ("M'appari" being the expression of said grief) loses his senses; he is indifferent to inheriting the title of the Count of Derby or to visits paid by Lady Harriet. Nancy and Plunkett arrange a scene meant to remind him of the Richmond market. When Lionel encounters his "Martha", his sanity is restored. The opera ends in a wedding.

The moment in which Lionel's aria is performed is significant: the tryst between Boylan and Molly is just about to take place. Bloom is still eating his lunch, accompanied by his friend, Richie Goulding, who recognises the voice of his brother-in-law, Simon Dedalus, who is performing the aria in the adjacent room. Joyce combines the passages from the aria and Bloom's thoughts in a peculiar fashion:

When first I saw that form endearing.

Richie turned.

Si Dedalus' voice, he said.

Brain tipped, cheek touched with flame, they listened feeling that flow endearing flow over skin limbs human heart soul spine. (273.3035)

$[\ldots]$

Sorrow from me seemed to depart.

Through the hush of air a voice sang to them, low, not rain, not leaves in murmur, like no voice of strings of reeds or what do you call them dulcimers, touching their still ears with words, still hearts of their each his remembered lives. Good, good to hear: sorrow from them each seemed to from both depart when first they heard. When first 
they saw, lost Richie, Poldy, mercy of beauty, heard from a person wouldn't expect it in the least, her first merciful love soft, oft loved word. (273.39274.5)

The music evokes the melancholy caused by the loss of a loved person, a situation the protagonist considers hopeless. It is underscored in the narrative plan by the use of epithets such as "lost Leopold", "lost Poldy" $(224,225)$, or contaminations, such as "Lionelleopold" (236). "A beautiful air, said Bloom lost Leopold. I know it well" (224).

The aria is in a way counterpointed with "Love's Old Sweet Song," a song introducing a theme of nostalgia caused by Bloom reminiscing of the once existing love between him and his wife. As Molly included it in her repertoire, it not only refers to the beginnings of her relationship with Bloom, but also to her current relationship with Boylan. In an earlier episode, "Lotus Eaters", Bloom associates his wife's infidelity with this particular piece. Therefore its title, which is worked into his meditations brought about by "M'appari", couples "Love's Old Sweet Song" with Lionel's lamentation.

Bloom, however, is unable to focus on the aria's lyrics; stealing into his thoughts are Boylan ("Full of hope and all delighted [...] Jingle all delighted" [274.1119]) and the intercourse that is about to take place. The protagonist's agitation increases together with the aria's dynamism. The associations formed by Bloom's mind also concern Martha and her letter he intends to respond to. Bloom suddenly realises his friend bears the same name as the heroine of Flotow's opera:

[...] Martha it is. Coincidence. Just going to write. Lionel's song. Lovely name you have. Can't write. Accept my little pres. Play on her heart strings purse strings too. She's a. I called you naughty boy. Still the name:

Martha. How strange! Today. (274.41275.6)

But the protagonist quickly turns his thoughts back to Molly, when the aria's lyrics evoke the memory of their first meeting:

Each graceful look...

First night when first I saw her at Matt Dillon's in Terenure. Yellow, black lace she wore. Musical chairs.

We two the last. Fate [...]. Lips laughing. Yellow knees.

Charmed my eye...

Singing. Waiting she sang. I turned her music. Full voice of perfume of what perfume does your lilac trees.

Bosom I saw, both full, throat warbling.

First I saw. She thanked me. Why did she me? Fate [...] Under a pear tree alone patio this hour in old Madrid one side in shadow Dolores she dolores. At me. Luring. Ah, alluring. (275.1628) 
"Waiting" is a song of a maid waiting by the window for her beloved, who is supposed to come and take her away. Bloom suddenly imagines that it is him whom Molly is supposed to meet that day. The music intensifies and Leopold, identifying himself with Lionel, cries out:

Martha! Ah, Martha!

Quitting all languor Lionel cried in grief, in cry of passion dominant to love to return with deepening yet with rising chords of harmony. In cry of Lionel loneliness that she should know, must Martha feel. For only her he waited. Where? Here there try there here all try where. Somewhere. (275.2934)

As Zack Bowen points out, the cry of tormented Lionel expresses Bloom's relationship with both Molly and with Martha: although Molly is "the lost one", the complaint is directed at Martha. Joyce uses these ambiguities. The exclamation "Co-me, thou lost one! / Co-me thou dear one!" (275.3536) also has a double meaning, as it underscores Bloom's sense of isolation, separation from his wife, and at the same time it excites his feelings for Martha: "Alone. One love. One hope. One comfort me. Martha, chest note, return" (275.3738; cf. Bowen 1995: 52). But unlike "Lionel-Simon", whose singing is met with general acclaim, Bloom's grief is not heard ("Bloom sang dumb" [276.35]). Bloom leaves the bar, and in his imagination the town crier is calling the hour of Molly and Boylan's meeting: "Four o' clock's all's well! Sleep! All is lost now. Drum? Pompedy" (289.3639). Bloom thinks the lovers' tryst is underway; the aria from The Sleepwalker returns, accompanied by drums.

In "Sirens", Joyce tells a story of infidelity and introduces opera songs into the plot using either allusions or easily identified quotes. Thereby, he creates symbolic relationships between his protagonists: Bloom, his pen friend Martha, his wife Molly, and finally his wife's lover, Boylan. Using musical pieces, the events signalled in the book are intensified and (re) defined, while Lionel's and Elvino's arias serve as a base for re-evaluating the main protagonist's situation.

Iwona Puchalska calls such an artistic device a „bricolage”, which she describes in Polish as "tinkering". But she uses the term by analogy with fine arts and independently of how Claude Lévi-Strauss and Ryszard Nycz define the term. She writes: "The idea of such a work consists in using different, often even contradicting elements, and moulding them into a new, coherent whole, which possesses its own meaning, but at the same time specifically updating the meaning of 'matter' from which the new work has been created. [...] Its openness is an expression of a highly sophisticated and truly original approach to literary works" (Puchalska 2007: 79). Thus an opera's libretto becomes not only an interpretative 
context, but also a point of reference necessary for understanding Joyce's idea of a musical intertext, which is crucial for the reception of the literary text. A musical piece can be therefore now perceived as a tool for the construction of a literary experience and for structuring the reception of the text.

\section{References}

Barska, Joanna (2012). “Staccato czy asyndeton? Kilka uwag o 'umuzycznionej' prozie powieściowej (na marginesie Syren Joyce'a)". Acta Universitatis Lodziensis. Folia Litteraria Polonica 16 (2): “Muzyka i muzyczność w literaturze od Młodej Polski do czasów najnowszych" 2: 7-33.

Beach, Sylvia (1959). Shakespeare and Company. New York: Harcourt.

Bowen, Zack (1995). Bloom's Old Sweet Song: Essays on Joyce and Music. Gainesville: University Press of Florida.

Budgen, Frank (1963). "James Joyce". In: James Joyce: Two Decades of Criticism. Ed. Eugene Jolas. (19-27). New York: The Vanguard Press.

Gilbert, Stuart (1963). James Joyce's Ulysses. New York: Random House.

Hodgart, Matthew J. C. and Ruth Bauerle (1997). Joyce's Grand Operoar: Opera in Finnegans Wake. Urbana and Chicago: University of Illinois Press.

Hodgart, Matthew, and Mabel Worthington (1959). Song in the Works of James Joyce. New York: Columbia University Press.

Joyce, James (1961). Ulysses: The Corrected Text. Eds. Hans Walter Gabler, Wolfhard Steppe, and Claus Melchior. New York: Random House.

Martin, Timothy (2009). "Music". In: James Joyce in Context. Ed. John McCourt. (275-284). Cambridge: Cambridge University Press.

Potts, Willard (ed.) (1979). Portraits of the Artist in Exile: Recollections of James Joyce by Europeans. Dublin: Wolfhound Press.

Puchalska, Iwona (2007). “'Majsterkowanie' Mozartem. Dziadów część III a Don Giovanni". Wielogłos 1-2: 69-80.

Wiegandt, Ewa (2002). “Problem tzw. muzyczności prozy powieściowej XX wieku". In: Muzyka i literatura. Ed. Andrzej Hejmej. (63-64). Kraków: Universitas. 